\title{
Geochemical characteristics of mafic and felsic igneous rocks (1.9-1.75 Ga) in the Lesser Himalaya: Regional variation and its implications for tectonic setting
}

\author{
RYUICHI SHINJO ${ }^{1}$, TOMOKI AMURO ${ }^{1}$, KOHEI OURA ${ }^{1}$, \\ KAZUYA OSHIRO $^{1}$, SHIRO TAHARA ${ }^{1}$ AND HARUTAKA \\ SAKAI $^{2}$ \\ ${ }^{1}$ Univ. Ryukyus \\ ${ }^{2}$ Kyoto Univ. \\ Presenting Author: rshinjo@sci.u-ryukyu.ac.jp
}

Major and trace element and Nd-Hf isotopic compositions of Paleoproterozoic meta-igneous rocks from the lower part of the Lesser Himalayan sequence provide insights into the nature of their source mantle and its tectonic setting [1]. We observed bimodal (basaltic and rhyolitic) magmatic compositions in these rocks; this type of volcanism generally occurs in areas of extensional tectonics, particularly rifts. Two types of mafic rocks are identified: within-plate type (subduction-unrelated, enriched mantle derived) rocks and $\mathrm{Nb}$-Ta-depleted, continental arc-like rocks. Within-plate type mafic rocks are dominant in the eastern Nepal, though similar rocks are also found in western Nepal. Although models for the tectonic setting of these igneous rocks remain controversial (e.g. passive margin, continental arc, continental rift with possible hotspot), our new geochemical data support the rift model associated with mantle plume activity, which evolved to a passive margin. The $\mathrm{Nb}$-Ta-depleted, arc-like rocks have lower $\varepsilon \mathrm{Nd}(\mathrm{t})(-1.7$ to 1.7$)$ and $\varepsilon \mathrm{Hf}(\mathrm{t})(0.9-4.4)$ than within-plate type rocks; we consider that these rocks are formed from the interaction of mantle-derived magmas with crustal components. All felsic rocks have similar or slightly lower $\varepsilon \mathrm{Nd}$ (t) $(-5.2$ to -0.1$)$ and $\varepsilon \mathrm{Hf}(\mathrm{t})(-6.5$ to 2.7$)$ values relative to arclike mafic rocks, suggesting relatively limited crustal interaction. They may be derived from juvenile crust of underplated mafic magmas. Most of the felsic rocks have remarkably low $\mathrm{Nb} / \mathrm{Ta}$ ratios $(<5)$, suggesting modification on their chemical composition by intensive sub-solidus magmatic-hydrothermal alteration.

[1] Shinjo et al. (2020), Island Arc 2020;29:e12369. 